\title{
Sistem Rangking Pemanfaatan Susu Bayi Menggunakan Analytical Network Process (ANP)
}

\author{
Rangking System of The Use baby Milk by Using \\ Analytical Network Process (ANP)
}

\author{
Ratih Adinda Destari \\ Universitas Potensi Utama \\ Jl. KL.Yos Sudarso Km. 6,5 No.3A Telp (061) 6640525 \\ ratih_adindadestari@yahoo.com
}

\begin{abstract}
Abstrak
Dalam mencari produk susu yang paling banyak diminati oleh konsumen tentunya konsumen harus mampu menentukan dan memilih produk susu bayi yang paling banyak dikonsumsi. Banyak produk susu bayi yang beredar di pasaran tetapi tidak semua produk susu bayi tersebut banyak dibeli oleh konsumen terutama ibu rumah tangga yang membutuhkan susu bayi yang bermanfaat bagi bayi mereka, ada susu bayi hanya dikonsumsi oleh beberapa orang saja, hal tersebut terjadi dikarenakan ada beberapa masalah diantaranya mengenai, harga, daya tahan, jumlah protein, jumlah mineral dan sebagainya. Tujuan dari penelitian ini memberikan referensi dan kemudahaan bagi para konsumen yang memiliki bayi untuk memilih susu formula mana yang paling baik berdasarkan nilai rangking yang diperoleh masing-masing produk susu. Susu formula bayi berbentuk cairan atau bubuk yang dibuat secara instan dengan formula tertentu dan memiliki kandungan nilai gizi, AA, DHA, Protein, Vitamin dan Mineral untuk perkembangan otak, jaringan otot dan tulang rangka, diberikan pada bayi dan anak-anak yang berfungsi sebagai pengganti ASI. Analytic Network Process (ANP) metode yang terdiri dari kriteria dan alternative yang memiliki keterhubungan antara elemen yang ada dalam kriteria (Ineer Dependence) dengan elemen yang ada di luar kriteria (Outer Dependence) memiliki kemampuan mendapatkan peringkat prioritas alternatif sebagai acuan pengambilan keputusan dalam penelitian ini.Berdasarkan analisis dan pembahasan dari dari hasil pengolahan data, dapat diketahui bahwa Susu Bayi Lactogen mendapat rangking 1 dengan bobot prioritas paling besar sebesar 0.2001atau 20\%, peringkat 2 adalah Bebelac dengan bobot prioritasnya 0.1925 atau 19\%, peringkat 3 adalah Nutrilon dengan bobot prioritasnya 0.1668 atau 17\%, peringkat 4 adalah Lactona dengan bobot prioritasnya 0.1594 atau 16\%, peringkat 5 adalah SGM dengan bobot prioritasnya 0.1447 atau 15\% dan peringkat 6 adalah Frisian Flag dengan bobot prioritasnya 0.1365 atau 14\%. Dari hasil tersebut maka Susu Bayi Bebelac memiliki bobot paling besar dan paling banyak dipergunakan oleh masyarakat. Hasil penelitian ini kedepannya bisa menjadi referensi oleh peneliti dan masyarakat dalam memilih produk Susu Bayi yang bermanfaat.
\end{abstract}

Kata Kunci: Sistem Pendukung Keputusan (SPK), Analytic Network Process (ANP), Prioritas.

\begin{abstract}
In searching for dairy products most in demand by consumers of course, consumers should be able to determine and select the baby milk products are the most widely consumed. Many baby milk products on the market but not all baby milk products are purchased by many consumers, especially housewives who need baby formula is beneficial for their baby, no baby milk only consumed by a few people, it happens because there are some problems including the price, durability, amount of protein, the amount of minerals and so on. The purpose of this study provide ease of reference and for consumers who have infant formula to choose which one is best based on the rank obtained by each dairy. Infant formula as a liquid or powder made in an instant with a certain formula and contains nutritional value, AA, DHA, Protein, Vitamins and Minerals for the development of the brain, muscle tissue and skeleton, given to infants and children that serves as a substitute ASI. Analytic Network Process (ANP) method which consists of criteria and alternatives that have linkages between elements within the criteria (Ineer Dependence) with elements that are outside the criteria (Outer Dependence) has the ability to get priority ranking alternative as a reference for decision making in this study.Berdasarkan analysis and discussion of the results of data processing, it is known that the Baby Milk Lactogen gets rank 1 with the highest priority weight of 0.2001atau 20\%, rank 2 is
\end{abstract}


Bebelac with weights priorities 0.1925 or $19 \%$, ranking 3 is Nutrilon weighing priorities 0.1668 or $17 \%$, ranking 4 is Lactona with weights priorities 0.1594 or 16\%, ranking 5 is SGM with weights priorities 0.1447 or $15 \%$ and rank 6 is Frisian Flag with weights priorities 0.1365 or $14 \%$. Based on these results the Baby Milk weighs Bebelac largest and most widely used by the community. The future results of this study could be a reference by researchers and the public in choosing baby milk products that are useful.

Keywords: Decision Support System (DSS), Analytic Network Process (ANP), Priority.

\section{PENDAHULUAN}

Kualitas anak tidak terlepas dari faktor yang mempengaruhinya, jika faktor baik yang mempengaruhinya, maka kualitas dan perkembangan anak akan baik, demikian sebaliknya jika faktor yang mempengaruhinya tidak baik maka kualitas dan perkembangan anak juga akan tidak baik. Ada 2 faktor yang mempengaruhi pertumbuhan anak yaitu faktor dari dalam (bawaan) dan faktor dari luar (lingkungan) dimana faktor luar sangat perlu diperhatikan sebagai dasar - dasar pembentukan kepribadian anak agar semakin berkualitas dan perkembangannya juga semakin baik (Eva et al. 2010)[1]. Banyak metode Sistem Pendukung Keputusan (SPK) yang telah digunakan dalam memecahkan persoalan, metode tersebut mempunyai kelemahan dan kehandalan serta kesesuaian dengan permasalahan yang dihadapi. Maka dalam memilih metode Sistem Pendukung Keputusan yang tepat perlu melakukan analisis permasalahan dan solusi yang diinginkan, dalam penelitian ini akan digunakan metode Sistem Pendukung Keputusan dengan metode Analytic Network Process (ANP) yang merupakan kelanjutan dari metode $A H P$, berdasarkan hasil penelitian Dr. Saati yang menemukan metode AHP, bahwa metode ANP mempunyai keunggulan dibandingkan dengan AHP dalam menyelesaiakan masalah yang lebih kompleks.Sistem pendukung keputusan merupakan sistem informasi interaktif yang menyediakan informasi, permodelan dan pemanipulasi data. Sistem ini itu digunakan untuk membantu pengambilan keputusan dalam situasi yang semi terstruktur dan situasi yang tidak terstruktur, dimana tak seorang pun mengetahui secara pasti bagaimana keputusan seharusnya di buat. (Alter, 2012; Kusrini, 2007; Asep Hender Rustiawan, et al. 2012)[2].

Pengambilan keputusan dalam pemecahan masalah multi kriteria membutuhkan sismatika dan metode yang handal (Nejad Attari, et al. 2008)[3]. Sistem pendukung keputusan ini membantu melakukan penilaian setiap perubahan kriteria, dan perubahan nilai bobot. Hal ini berguna untuk memudahkan pengambilan keputusan yang terkait dengan masalah system rangking pemanfaatan susu bayi menggunakan metode Analytic Network Process, sehingga akan di dapatkan dipastikan susu mana yang paling layak (baik) untuk di konsumsi oleh kalangan masyarakat luas.

Hasil yang diharapkan dalam penelitian ini dapat diperoleh suatu metode rangking pemanfaatan susu bayi yang berkualitas dan optimal dengan menggunakan metode ANP. Pemanfaatan susu bayi yang terpilih tersebut dapat direkomendasikan untuk digunakan sebagai media penyampaian informasi pada masyarakat tentang produk susu bayi yang berkualitas dan mempunyai nilai gizi yang baik untuk dikonsumsi bayi.

\section{METODE PENELITIAN}

Menurut Turban (Iskandar, 2009), Sistem pendukung keputusan (Decision Support System/ DSS) merupakan suatu pendekatan untuk mendukung pengambilan keputusan. Sistem pendukung keputusan menggunakan data, memberikan antarmuka pengguna yang mudah, dan dapat menggabungkan yang mudah, dan dapat menggabungkan pemikiran pengambilan keputusan. Sistem Pendukung Keputusan merupakan sebuah sistem yang dapat mendukung para pengambil keputusan manajerial dalam situasi keputusan semi terstruktur. Sistem pendukung keputusan dimaksudkan untuk menjadi alat bantu bagi para pengambil keputusan untuk memperluas kapabilitas mereka, namun bukan untuk menggantikan penilaian. 


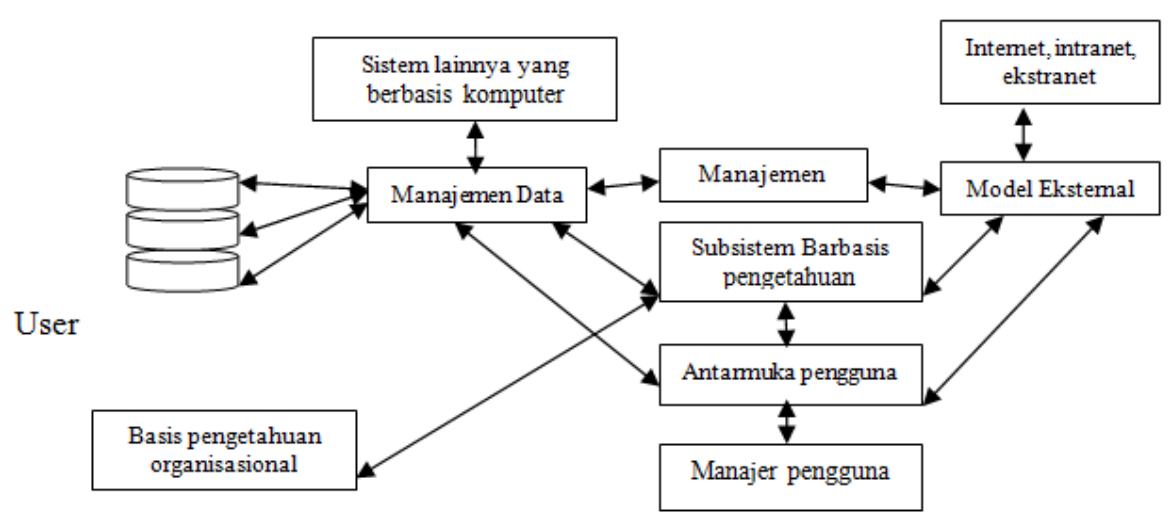

Gambar 1. Komponen SPK

Gambar 1 memperlihatkan Menurut Asep Hendar Rustiawan, et,al, (2012)[2], Sistem Pendukung Keputusan terdiri atas tiga komponen penting utama untuk menentukan kapabilitas teknis, yaitu:

1. Subsistem manajemen data, subsistem manajemen data memasukkan satu database yang berisi data yang relevan untuk situasi dan dikelola oleh perangkat lunak yang disebut sistem manajemen database (DBMS)

2. Subsistem manajemen model, merupakan paket perangkat lunak yang memasukkan model keuangan, statistik, ilmu manajemen atau model kuantitatif lainnya yang memberikan kapabilitas analitik dan manajemen perangkat lunak yang tepat.

3. Antarmuka pengguna, pengguna berkomunikasi dengan memerintahkan DSS melalui subsistem ini.

4. Subsistem berbasis pengetahuan, sub sistem ini adalah operasional yang memberikan manfaat bagi tiga komponen tersebut.

Menurut Meilia Nur Indah Susanti (2011)[5], Metode Analytic Process (ANP) merupakan pengembangan metode Analytic Hierarchy Process (AHP). Metode ANP mampu memperbaiki kelemahan metode AHP berupa kemampuan merekomendasikan keterkaitan pada metode ANP, ada 2 jenis yaitu keterkaitan dalam satu set elemen (inner dependence) dan keterkaitan antar elemen yang berbeda (outer dependence). Adanya keterkaitan tersebut menyebabkan metode ANP lebih kompleks dibandingkan dengan metode AHP.

Menurut Pudji Astuti,et.al, (2011)[6], untuk mendapatkan bobot dari setiap elemen ANP digunakan kuisioner perbandingan berpasangan yang di ambil dari preperensi para pakar dan kemudian diolah dengan Software Superdecision, dalam pengambilan keputusan sering dihadapkan pada beberapa faktor yang menjadi pertimbangan yang terstruktur kompleks terkait satu sama lain. Metode ANP mampu mengakomodir persoalan.

Menurut Luhur, et al (2010)[7], Secara umum langkah-langkah yang harus dilakukan dalam menggunakan ANP adalah sebagai berikut :

1. Mendefinisikan masalah dan menentukan kriteria solusi yang diinginkan.

2. Menentukan prioritas elemen.

3. Membuat perbandingan pasangan

Matrix perbandingan berpasangan diisi menggunakan bilangan untuk merepresentasikan kepentingan relatif dari suatu elemen terhadap elemen yang lain.

4. Sintesis

Melakukan pertimbangan pertimbangan terhadap perbandingan berpasangan disintesis untuk memperoleh keseluruhan prioritas. Hal hal yang dilakukan adalah :

a. Menjumlahkan nilai nilai dari setiap kolom pada matrix

b. Menentukan pembobotan komponen dari sudut pandang manajerial

c. Membuat matrix perbandingan berpasangan yang menggambarkan kontribusi atau pengaruh setiap elemen atas setiap kriteria. Perbandingan dilakukan berdasarkan 
penilaian dari pengambilan keputusan dengan menilai tingkat kepentingan suatu elemen.

d. Mengumpulkan semua data perbandingan berpasangan dan memasukkan nilai-nilai kebalikannya serta nilai satu di sepanjang diagonal utama, prioritas masing-masing kriteria dicari dan konsistensi diuji.

e. Menentukan eigenvector dari matrix yang telah dibuat pada langkah ketiga.

f. Ulangi langkah c, d dan e untuk semua kriteria.

g. Membuat unweighted super matrix dengan cara memasukkan semua eigen vector yang telah dihitung pada langkah 5 kedalam sebuah super matrix.

h. Membuat weighted super matrix dengan cara melakukan perkalian setiap isi unweighted supermatrix terhadap matrix perbandingan kriteria

i. Membuat limiting supermatrix dengan cara memangkatkan super matrix secara terus menerus hingga angka disetiap kolom dalam satu baris sama besar, setelah itu dilakukan normalisasi terhadap limiting supermatrix

j. Hitung consistency index $(\mathrm{CI})$ dengan rumus $: \mathrm{CI}=(\lambda \max -\mathrm{n}) / \mathrm{n}$

Dimana : $\mathrm{n}=$ banyaknya elemen

k. Hitung Rasio Konsistensi dengan rumus : $\mathrm{CR}=\mathrm{CI} / \mathrm{IR}$

Dimana : $\mathrm{CR}=$ Consistency Ratio

$\mathrm{CI}=$ Consistency Index

$\mathrm{IR}=$ Indeks Random

\section{HASIL DAN PEMBAHASAN}

\subsection{Analisis Kebutuhan Data}

Analisa kebutuhan atau Requirement analysis merupakan suatu kegiatan untuk menentukan spesifikasi atau kondisi yang harus dipenuhi dalam suatu penelitian, yang mempertimbangkan berbagai kebutuhan yang berhubungan antar berbagai pemangku kepentingan. Kebutuhan dari hasil analisis ini harus dapat dilaksanakan untuk pembuatan kuesioner dan cara melakukan analisa kuesioner. Untuk menetapkan pemanfaatan nilai susu bayi berdasarkan nilai tertinggi, langkah yang harus dilakukan adalah menentukan kriteria-kriteria yang digunakan, kriteria yang digunakan adalah pembobotan penilaian terhadap kriteria-kriteria yang ada.

\subsubsection{Analisis Metode Keterhubungan Network ANP pada Rangking Pemanfaatan Susu bayi}

Untuk memenuhi keberlangsungan penelitian ini peneliti akan memperlihatkan tahapan penilaian dalam studi kasus sistem rangking pemanfaatan susu bayi dengan metode ANP. Langkah-langkah yang dilakukan untuk tahap selanjutnya adalah sebagai berikut :

a. Tujuan

Rangking pemamfaatan susu bayi mempunyai tujuan untuk membantu kalangan masyarakat memilih produk susu mana terbaik melalui merk yang beredar di kalangan masyarakat, melalui penilaian dan evaluasi kuesioner dari nilai index konsistensi dari matrik berpasangan.

b. Alternatif

Alternatif yaitu nama-nama yang menjadi objek utama dalam penelitian yang tahap selanjutnya akan diproses untuk penentuan kasus. Beberapa alternatif yang peneliti gunakan adalah Merk Susu Frisian Flag, Lactogen, Nutrilon, Lactona, Bebelac dan SGM.

c. Kriteria

Yaitu atribut-atribut/ elemen utama yang mendukung proses perolehan eleman yang berkaitan dengan kasus yang peneliti butuhkan. Kriteria-kriteria yang digunakan dalam penelitian ini adalah sebagai berikut:

Tabel 1 Jenis Kriteria

\begin{tabular}{clc}
\hline No. & \multicolumn{1}{c}{ Keterangan } & Singkatan \\
\hline 1. & Komposisi kandungan nilai gizi & KNG \\
\hline 2. & Pemakaian produk & PMP \\
\hline 3. & Penawaran produk & PWP \\
\hline
\end{tabular}


d. Sub Kriteria

Merupakan objek turunan dari kriteria/ elemen dari penelitian yang akan diproses untuk menentukan hasil dari studi kasus. Adapun sub kriteria yang digunakan pada penelitian ini yaitu :

Tabel 2 Jenis Sub Kriteria

\begin{tabular}{cl}
\multicolumn{2}{c}{ Nama Sub Kriteria } \\
No. & \\
\hline 1. & Kandungan nilai AA/ DHA \\
\hline 2. & Prebiotik/ Simbiotik \\
\hline 3. & Jumlah Protein \\
\hline 4. & Jumlah Mineral \\
\hline 5. & Efek samping \\
\hline 6. & Daya Tahan \\
\hline 7. & Cara Membuat \\
\hline 8. & Harga \\
\hline 9. & Promosi \\
\hline 10. & Ukuran Volume \\
\hline 11. & Kemasan Produk \\
\hline
\end{tabular}

Dibawah ini terdapat struktur hirarki dari metode ANP, yang memiliki saling keterhubungan.

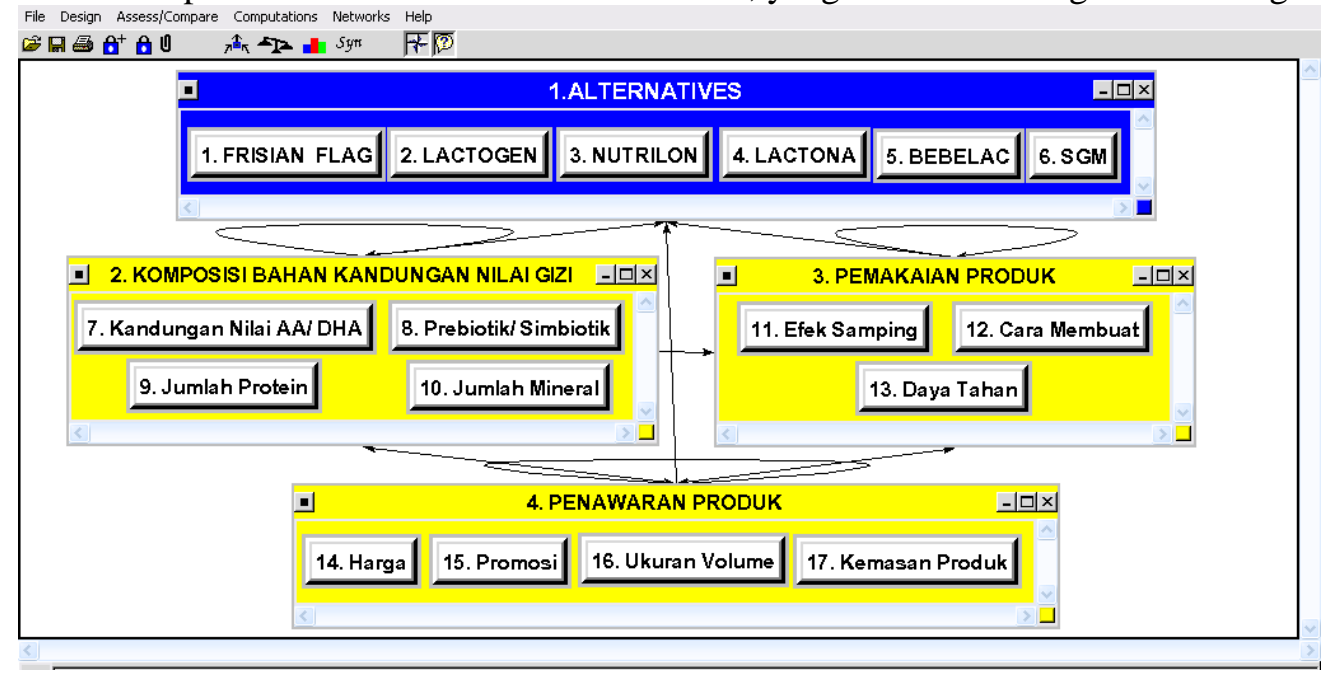

Gambar 2. Struktur Hirarki ANP Sistem Rangking Pemanfaatan Susu Bayi

Penjelasan gambar 2:

a. Alternatif merupakan nama-nama merk susu yang ada didalam node digunakan dalam penelitian ini sebagai objek utama diantaranya adalah : Frisian Flag, Lactogen, Nutrilon, Lactona, Bebelac dan SGM.

b. Kriteria (Elemen) yang merupakan atribut-atribut objek penilaian yang memiliki keterhubungan setelah alternatif yang memiliki keterkaitan. Kriteria tersebut adalah Komposisi bahan kandungan nilai gizi, Pemakaian produk, dan Penawara produk.

c. Sub Kriteria berfungsi sebagai penilaian pada node yang memiliki keterhubungan dengan kriteria/ elemen. Beberapa sub kriteria tersebut adalah efek samping, daya tahan, cara membuat, harga, promosi, ukuran volume ,kemasan produk, kandungan nilai AA/DHA, prebiotik/simbiotik, jumlah protein, jumlah mineral.

d. Inner Defendensi berbentuk oval yang tidak penuh, memiliki artinya antara sesama node dalam 1 klaster yang satu dengan node yang lainnya memiliki keterhubungan didalam 1 kriteria. 
e. Outer Defendensi memiliki artinya keterhubungan antara klaster dan node yang diberi tanda garis arah panah penghubung, yang memiliki arti satu dengan node yang lainnya memiliki keterhubungan baik antara alternatif, kriteria dan sub kriteria

\subsection{Perancangan Kuesioner}

Dari data kuesioner yang dibagikan pada 5 responden yang telah direkap, akan menghasilkan data tabel yang cukup banyak sehingga hanya akan ditunjukan satu buah Inner Dependence sebagai Kriteria pemakaian produk dan dua buah bentuk Outer Dependence yaitu sub kriteria daya tahan terhadap kluster alternatif pemanfaatan produk.

\subsubsection{Rekapitulasi Hasil Kuesioner}

Pada Tabel 3 menunjukkan hasil rekapitulasi data kuesioner dari salah satu bentuk keterhubungan outer dependence dari kluster atau kriteria pemanfaatan produk pada sub kriteria daya tahan dengan membandingkan antar node pada alternatif yang terdiri dari : Frisian Flag, Lactogen, Nutrilon, Lactona, Bebelac dan SGM. Sedangkan bentuk matrix berpasangan yang dihasilkan dari tabel 3.3 untuk sub kriteria daya tahan yang berbentuk matrix 6x6 terlihat pada tabel 4 kedua tabel tersebut terlihat berturut seperti dibawah ini :

Tabel 3. Hasil rekapitulasi kuesioner berdasarkan Kriteria Pemanfaatan Produk

\begin{tabular}{|c|c|c|c|c|c|c|c|c|}
\hline No & Alt1 & Alt2 & R1 & R2 & R3 & R4 & R5 & Rata-Rata \\
\hline 1 & Frisian Flag & Lactogen & -4 & -3 & -2 & -3 & -3 & -3.0 \\
\hline 2 & Frisian Flag & Nutrilon & -2 & -4 & -3 & -3 & -3 & -3.0 \\
\hline 3 & Frisian Flag & Lactona & 2 & -4 & -2 & -2 & -4 & -2.0 \\
\hline 4 & Frisian Flag & Bebelac & 3 & 2 & 3 & 4 & 3 & 3.0 \\
\hline 5 & Frisian Flag & SGM & -4 & 6 & 2 & 4 & 2 & -2.0 \\
\hline 6 & Lactogen & Nutrilon & -4 & 4 & 5 & 3 & 2 & 2.0 \\
\hline 7 & Lactogen & Lactona & 2 & 3 & 3 & 4 & 3 & 3.0 \\
\hline 8 & Lactogen & Bebelac & 5 & 4 & 5 & 4 & 2 & 4.0 \\
\hline 9 & Lactogen & SGM & 3 & 3 & 4 & 2 & 3 & 3.0 \\
\hline 10 & Nutrilon & Lactona & 2 & -4 & -2 & -2 & -4 & -2.0 \\
\hline 11 & Nutrilon & Bebelac & 3 & 3 & 2 & 4 & 3 & 3.0 \\
\hline 12 & Nutrilon & SGM & 4 & 5 & 3 & -4 & 2 & 2.0 \\
\hline 13 & Lactona & Bebelac & 2 & 3 & 3 & 3 & 4 & 3.0 \\
\hline 14 & Lactona & SGM & 4 & 3 & 2 & 3 & 3 & 3.0 \\
\hline 15 & Bebelac & SGM & 4 & 2 & 6 & -4 & 2 & -2.0 \\
\hline \multicolumn{9}{|c|}{ Tabel 4. Matriks Berpasangan untuk Sub Kriteria Daya Tahan } \\
\hline \multicolumn{2}{|c|}{ Daya Tahan } & Frisian Flag & Lactogen & & & Lactona & Bebelac & SGM \\
\hline \multicolumn{2}{|c|}{ Frisian Flag } & 1 & $1 / 3$ & \multicolumn{2}{|c|}{$1 / 3$} & $1 / 2$ & 3 & $1 / 2$ \\
\hline \multicolumn{2}{|c|}{ Lactogen } & 3 & 1 & \multicolumn{2}{|c|}{2} & 3 & 4 & 3 \\
\hline \multicolumn{2}{|c|}{ Nutrilon } & 3 & $1 / 2$ & \multicolumn{2}{|c|}{1} & $1 / 2$ & 3 & 2 \\
\hline \multicolumn{2}{|c|}{ Lactona } & 2 & $1 / 3$ & \multicolumn{2}{|c|}{2} & 1 & 3 & 3 \\
\hline \multicolumn{2}{|c|}{ Bebelac } & $1 / 3$ & $1 / 4$ & \multicolumn{2}{|c|}{$1 / 3$} & $1 / 3$ & 1 & $1 / 2$ \\
\hline \multicolumn{2}{|c|}{ SGM } & 2 & $1 / 3$ & \multicolumn{2}{|c|}{$1 / 2$} & $1 / 3$ & 2 & 1 \\
\hline
\end{tabular}

Langkah berikutnya adalah dengan melakukan penjumlahan ditiap-tiap kolom. Dari hasil Penjumlahan menggunakan 4 (empat) digit dibelakang koma, dimana nanti ini berguna untuk pembulatan dalam penghitungan.

Adapun hasilnya dapat dilihat pada tabel 5

Tabel 5. Hasil bobot Sub Kriteria Daya Tahan

\begin{tabular}{lcccccc}
\hline Kriteria & Frisian Flag & Lactogen & Nutrilon & Lactona & Bebelac & SGM \\
\hline Frisian Flag & 1.0000 & 0.3333 & 0.3333 & 0.5000 & 3.0000 & 0.5000 \\
\hline Lactogen & 3.0000 & 1.0000 & 2.0000 & 3.0000 & 4.0000 & 3.0000 \\
\hline Nutrilon & 3.0000 & 0.5000 & 1.0000 & 0.5000 & 3.0000 & 2.0000 \\
\hline Lactona & 2.0000 & 0.3333 & 2.0000 & 1.0000 & 3.0000 & 3.0000 \\
\hline Bebelac & 0.3333 & 0.2500 & 0.3333 & 0.3333 & 1.0000 & 0.5000 \\
\hline
\end{tabular}




\begin{tabular}{lcccccc}
\hline SGM & 2.0000 & 0.3333 & 0.3333 & 0.3333 & 2.0000 & 1.0000 \\
\hline Jumlah & 11.3333 & 2.6999 & 6.1666 & 5.6666 & 16.0000 & 10.0000 \\
\hline
\end{tabular}

Selanjutnya akan dilanjutkan ke tahap perhitungan kriteria berpasangan untuk membuat matriks berpasangan yang di ubah kedalam bilangan desimal

$\mathrm{A}=\quad$\begin{tabular}{llllll|}
1.0000 & 0.3333 & 0.3333 & 0.5000 & 3.0000 & 0.5000 \\
3.0000 & 1.0000 & 2.0000 & 3.0000 & 4.0000 & 3.0000 \\
3.0000 & 0.5000 & 1.0000 & 0.5000 & 3.0000 & 2.0000 \\
2.0000 & 0.3333 & 2.0000 & 1.0000 & 3.0000 & 3.0000 \\
0.3333 & 0.2500 & 0.3333 & 0.3333 & 1.0000 & 0.5000 \\
2.0000 & 0.3333 & 0.5000 & 0.3333 & 2.0000 & 1.0000 \\
\hline
\end{tabular}

Normalisasi matriks tahap ke kedua :

\begin{tabular}{|llllll|}
\hline 1.0000 & 0.3333 & 0.3333 & 0.5000 & 3.0000 & 0.5000 \\
3.0000 & 1.0000 & 2.0000 & 3.0000 & 4.0000 & 3.0000 \\
3.0000 & 0.5000 & 1.0000 & 0.5000 & 3.0000 & 2.0000 \\
2.0000 & 0.3333 & 2.0000 & 1.0000 & 3.0000 & 3.0000 \\
0.3333 & 0.2500 & 0.3333 & 0.3333 & 1.0000 & 0.5000 \\
2.0000 & 0.3333 & 0.5000 & 0.3333 & 2.0000 & 1.0000 \\
\hline \hline 1.0000 & 0.3333 & 0.3333 & 0.5000 & 3.0000 & 0.5000 \\
3.0000 & 1.0000 & 2.0000 & 3.0000 & 4.0000 & 3.0000 \\
3.0000 & 0.5000 & 1.0000 & 0.5000 & 3.0000 & 2.0000 \\
2.0000 & 0.3333 & 2.0000 & 1.0000 & 3.0000 & 3.0000 \\
0.3333 & 0.2500 & 0.3333 & 0.3333 & 1.0000 & 0.5000 \\
2.0000 & 0.3333 & 0.5000 & 0.3333 & 2.0000 & 1.0000 \\
\hline
\end{tabular}

$=\begin{array}{rrrrrr}6.0000 & 25.3333 & 13.5000 & 18.0000 & 4.0833 & 7.8333 \\ 1.9166 & 6.0000 & 3.5833 & 4.0833 & 1.0555 & 2.1944 \\ 3.5833 & 13.8333 & 6.0000 & 7.8333 & 2.1944 & 3.6666 \\ 3.3333 & 10.8333 & 5.6666 & 6.0000 & 1.9166 & 3.5833 \\ 10.8333 & 38.0000 & 22.5000 & 25.3333 & 6.0000 & 13.8333 \\ 5.6666 & 22.5000 & 10.0000 & 13.5000 & 3.5833 & 6.0000\end{array}=\begin{array}{r}74.4166 \\ 18.8331 \\ 37.1109 \\ 31.3331 \\ 114.4999 \\ 61.2499 \\ 337.4435 \\ \hline\end{array}$

Dari hasil normalisasi yang kedua, terlihat hasil penjumlahan baris dibagi dengan jumlah keseluruhan dari hasil tersebut:

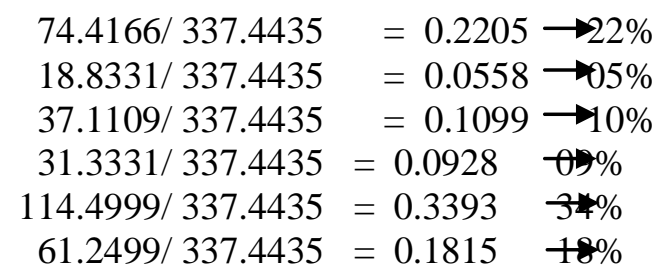


Didapatkan hasil perhitungan skala prioritas untuk masing-masing kriteria. Pada baris pertama untuk penilaian kriteria pemanfaatan produk dengan nilai susu bayi Frisian Flag 0.2205 atau 22\%, baris kedua susu bayi Lactogen 0.0558 atau 5\%, baris ketiga susu bayi Nutrilon 0.1099 atau 10\%, baris ke empat susu bayi Lactona 0,0928 atau 9\%, baris ke lima susu bayi Bebelac 0,3393 atau $34 \%$, baris ke enam susu bayi SGM dengan nilai 0.1815 atau $18 \%$.

\subsection{Pengujian dengan Superdecision}

Jika pembuatan masing-masing cluster sesuai dengan alternatif dan kriteria telah selesai, tahap selanjutnya adalah klik kanan pada cluster alternatif terlebih dahulu kemudian klik create node in cluster lalu klik create another untuk membuat node-node lainnya. Setelah semua node terbentuk klik save seperti terlihat pada gambar 3

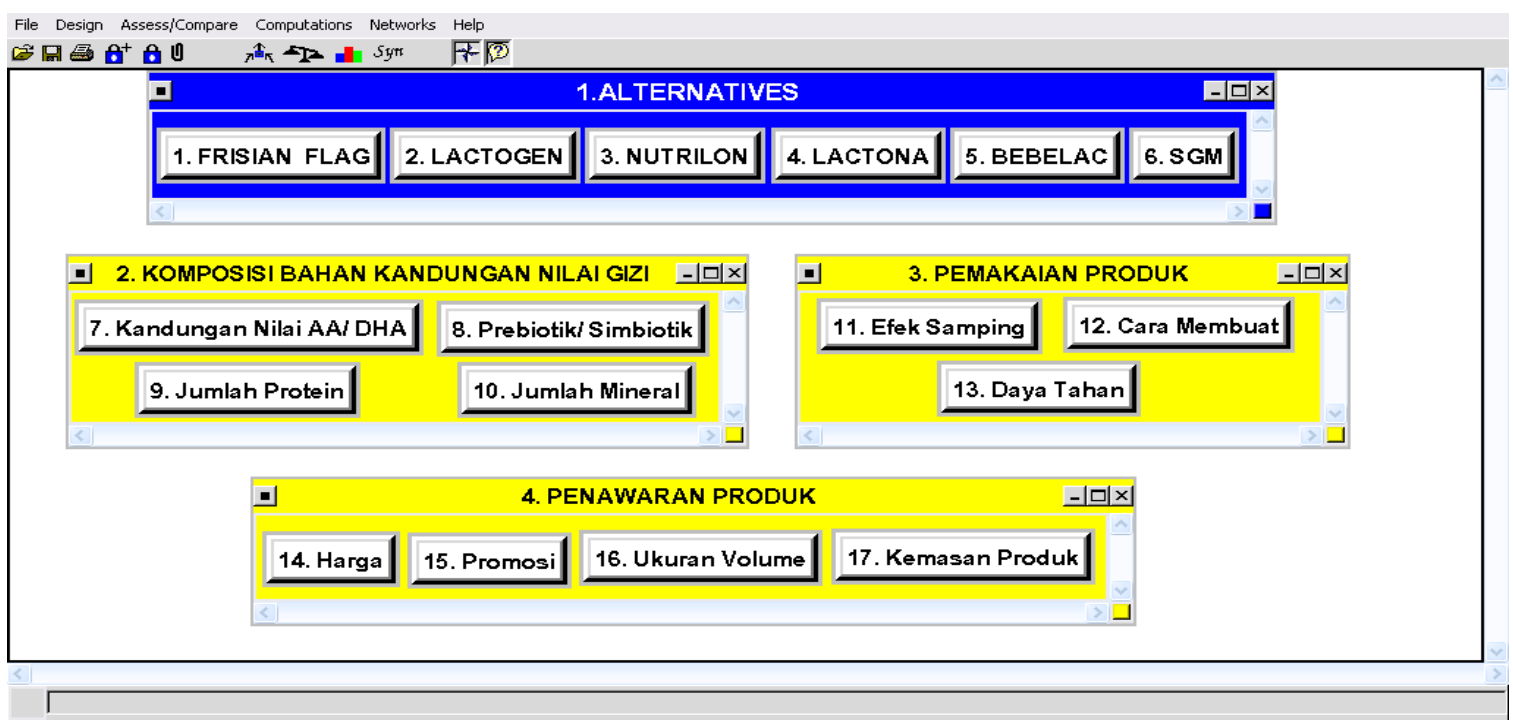

Gambar 3. Membuat Node didalam Cluster

Dari semua cluster dan node yang telah terbentuk, maka tahap selanjutnya adalah menghubungkan node-node yang ada dalam cluster kriteria dengan node-node yang ada dalam cluster sub kriteria. Selanjutnya dari node-node yang ada dalam cluster sub kriteria daya tahan dengan node-node yang ada dalam cluster alternatif. Misalnya klik kanan pada node Frisian Flag, Lactogen, Nutrilon, Lactona, Bebelac, SGM selanjutnya pilih node connexions form, pilih node yang akan dihubungkan dengan klik oke seperti gambar 4.

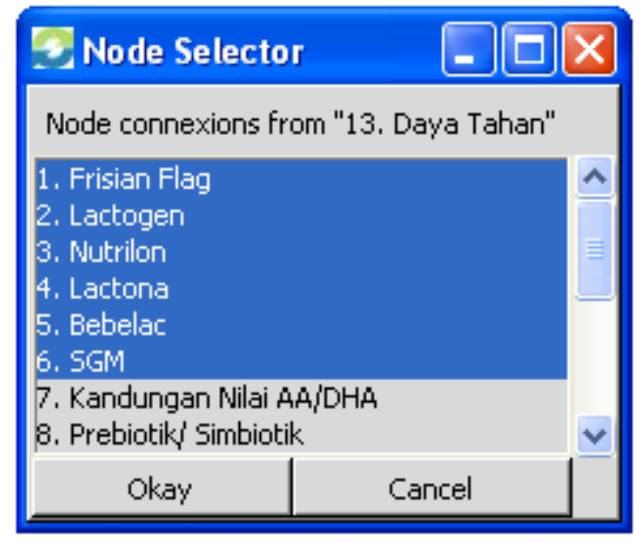

Gambar 4. Menghubungkan masing-masing Cluster 
Pada tahap ini, peneliti inputkan nilai dari hasil kuesioner yang telah diisi oleh responden, kemudian masukkan masing-masing nilai dari seluruh cluster yang telah dikoneksikan pada tab menu matrix seperti yang terlihat pada gambar 5 .

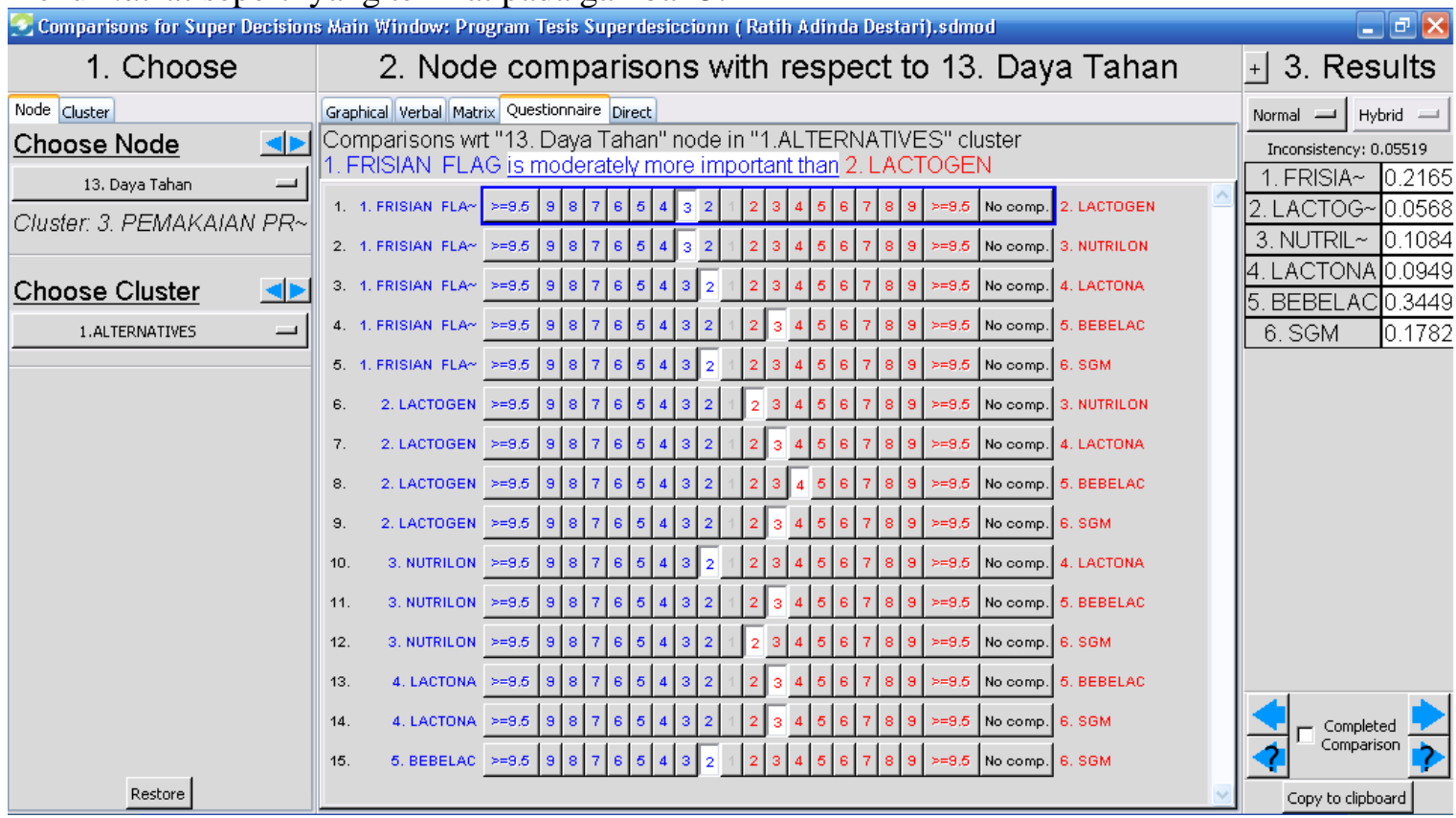

Gambar 5. Kuesioner Responden dalam perbandingan berpasangan

Untuk melihat hasil matriks dari kuesioner, pilih menu matriks setelah tampilan kuesioner yang terlihat pada gambar 5. seperti yang terlihat di atas, jika telah dipilih maka akan terlihat tampilan dari matriks seperti terlihat pada gambar 6.

\section{Node comparisons with respect to 13. Daya Tahan}

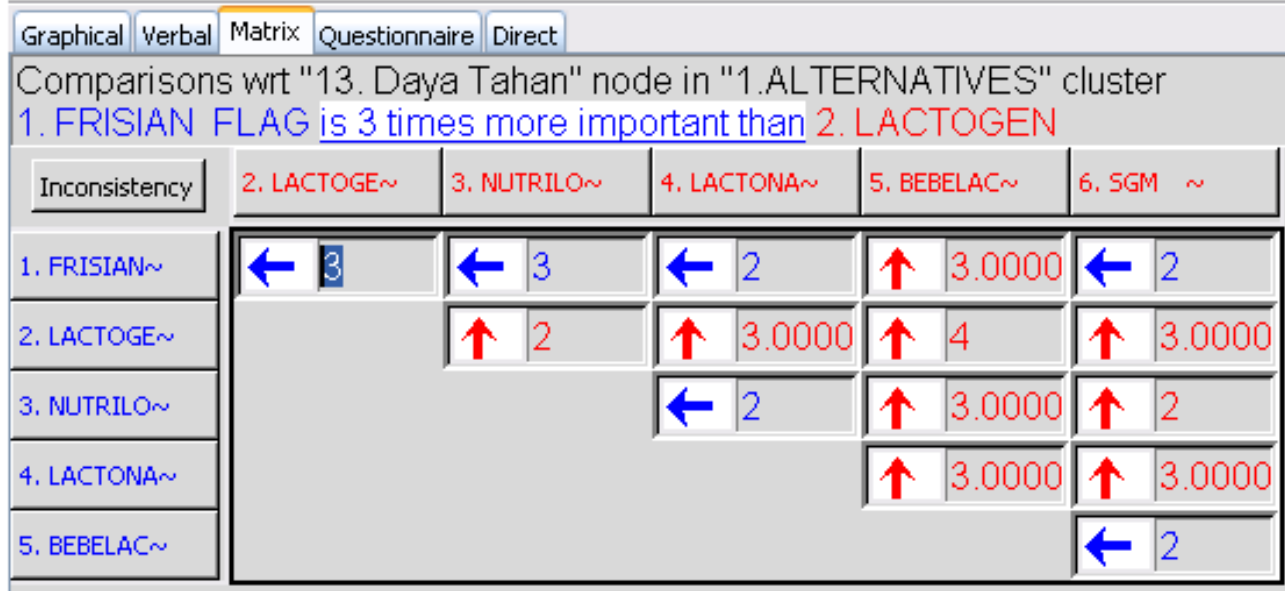

Gambar 6. Matriks hasil kuesioner Input

Untuk menganalisa hasil komputasi ANP dengan menampilkan rasio konsistensi untuk perbandingan matriks setiap cluster seperti terlihat pada gambar 7 . 


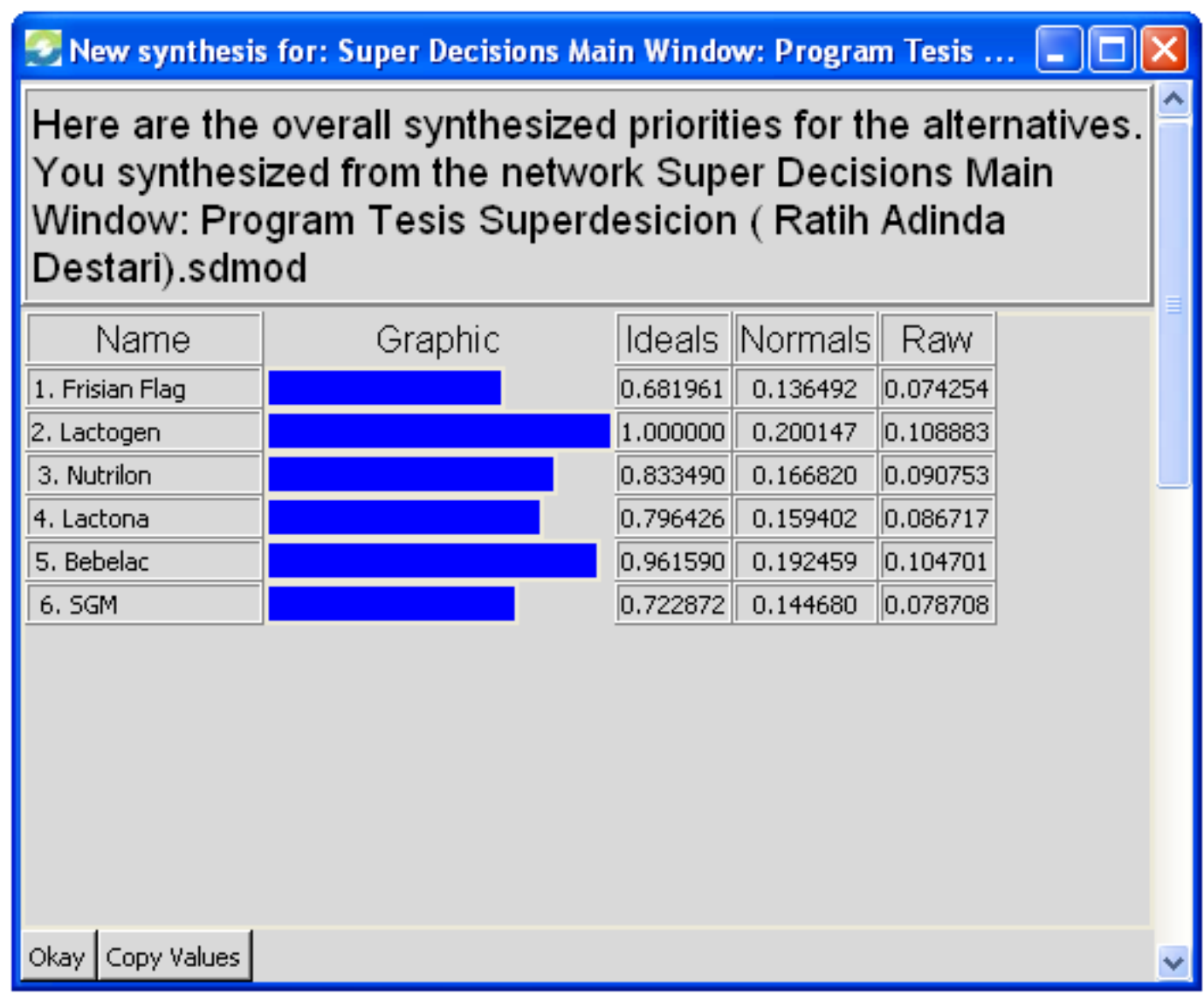

Gambar 7. Tampilan hasil akhir dengan software superdesicion

Tampilan laporan lengkap dari seluruh hasil analisa yang telah dilakukan. Pertama klik menu computations, kemudian pilih full report seperti yang terlihat pada gambar 8 .

\section{Report for toplevel}

This is a report for how alternatives fed up through the system to give us our synthesized values. Return to main menu

\section{Alternative Rankings}

\begin{tabular}{|l|c|c|c|c|c|c|}
\hline Graphic & Alternatives & Total & Normal & Ideal & Ranking \\
\hline \hline & 1. Frisian Flag & 0.0743 & 0.1365 & 0.6820 & 6 \\
\hline \hline & 2. Lactogen & 0.1089 & 0.2001 & 1.0000 & 1 \\
\hline \hline & 3. Nutrilon & 0.0908 & 0.1668 & 0.8335 & 3 \\
\hline \hline & 4. Lactona & 0.0867 & 0.1594 & 0.7964 & 4 \\
\hline \hline & 5. Bebelac & 0.1047 & 0.1925 & 0.9616 & 2 \\
\hline \hline & 6. SGM & 0.0787 & 0.1447 & 0.7229 & 5 \\
\hline
\end{tabular}

Gambar 8. Laporan Lengkap Hasil Analisa Pemanfaatan Susu Bayi

3.4 Hasil Akhir Pemanfaatan Susu Bayi di Superdecision 
Hasil akhir dari studi kasus dari penilaian yang telah di urutkan berdasarkan rangking yang diperoleh adalah sebagai berikut:

Tabel 6. Hasil Akhir Pemanfaatan Susu Bayi

\begin{tabular}{|l|c|c|}
\hline Nama Node & Nilai Eigen Vektor & Rangking \\
\hline Lactogen & 0.2001 & 1 \\
\hline Bebelac & 0.1925 & 2 \\
\hline Nutrilon & 0.1668 & 3 \\
\hline Lactona & 0.1594 & 4 \\
\hline SGM & 0.1447 & 5 \\
\hline Frisian Flag & 0.1365 & 6 \\
\hline
\end{tabular}

Dari hasil rangking yang diperoleh, dari masing-masing produk susu maka dapat di ambil kesimpulan, bahwa peringkat rangking pertama di peroleh oleh produk susu Lactogen dengan perolehan nilai eigen vektornya 0.2001 , peringkat rangking ke dua diperoleh oleh produk susu Bebelac, dengan perolehan nilai eigen vektornya 0.1925, peringkat rangking ketiga Nutrilon dengan perolehan nilai eigen vektornya 0.1668 , peringkat rangking ke empat di peroleh oleh produk susu Lactona dengan perolehan nilai eigen vektornya 0.1594 , peringkat rangking ke lima di peroleh oleh produk susu SGM dengan perolehan nilai eigen vektornya 0.1447 , peringkat rangking ke enam di peroleh oleh produk susu Frisian Flag.

\section{KESIMPULAN}

Berdasarkan hasil penelitian yang telah diuraikan maka dapat disimpulkan berdasarkan pemahaman dari penelitian sistem rangking pemanfaatan susu bayi adalah sebagai berikut :

1. Dari sistem pendukung keputusan dengan menggunakan ANP mampu menyelesaikan permasalahan dalam menentukan pemanfaatan rangking susu bayi bagi konsumen dan dinas kesehatan.

2. Penggunaan metode ANP dalam menyelesaikan permasalahan membutuhkan keterhubungan antara node dengan kluster berdasarkan inner dependence dan outer dependence yang menyebabkan perolehan hasil ANP lebih akurat dibandingkan AHP.

3. Dengan adanya pengabungan antara sistem dengan metode yang peneliti digunakan, mampu memberikan solusi kepada konsumen yang baru mempunyai bayi, secara cepat dan lebih efisien berdasarkan hasil yang telah diperoleh dari peneliti.

4. Hasil akhir yang diperoleh, menunjukkan bahwa sebagian besar responden memilih Susu Bayi Lactogen dengan prosentasi sebesar $20 \%$ dengan tingkat kesalahan sebesar $5,3 \%$ atau 0.052596 .

\section{SARAN}

Setelah mengemukakan beberapa kesimpulan, peneliti dapat memberikan beberapa saran yang dapat digunakan untuk pengembangan metode ANP agar dapat lebih baik lagi dari sebelumnya. Saran tersebut adalah :

1. Dalam metode yang telah dibuat, peneliti menyadari bahwa masih banyak kekurangan dalam sistem dan metode yang digunakan. Diharapkan kepada pembaca penelitian ini dapat memberikan saran, kritik serta ide-ide cemerlang agar hasil yang diperoleh lebih baik lagi dari sebelumnya.

2. Dari sistem dan metode yang di gunakan perlu membandingkan hasilnya dengan menggunakan software lainnya selain superdecision, agar dapat dengan mudah ditemukan kelemahannya.

3. Data kuesioner untuk responden perlu diperbanyak lagi, agar hasil yang diperoleh bisa lebih baik dan lebih akurat. Karena dalam penelitian ini, peneliti hanya menggunakan 5 kuesioner untuk responden. 
4. Berdasarkan hasil yang diperoleh dari penelitian ini, hasilnya dapat dijadikan referensi oleh peneliti lain dan Dinas Kesehatan.

\section{UCAPAN TERIMA KASIH}

Penulis mengucapkan terima kasih kepada Universitas Potensi Utama yang telah memberi dukungan financial terhadap penelitian ini.

\section{DAFTAR PUSTAKA}

[1] Eva Latifa, et.al, 2010. Pengaruh Pemberian Asi Dan Stimulasi Psikososial Terhadap Perkembangan Sosial Emosi Anak balita Pada Keluarga Ibu Berkerja Dan Tidak Berkerja, Vol 3, No.1, Januari.

[2] Asep Hender Rustiawan, et.al, 2012. Sistem Pendukung Keputusan Penyeleksian Calon Siswa Baru di SMA Negeri 3 Garut, Vol 9, No. 21. 2012.

[3] M. Yousefi Nejad Attari, et.al. 2012. A Decision Making Model For Qutsourcing Of manufacturing Activities By ANP And DEMATEL Under Fuzzy Environmenx, Vol 23. Number. 3 2012..

[4] Iskandar Z. Nasibu, 2009. Penerapan Metode AHP Dalam Sistem Pendukung Keputusan Penerapan Karyawan Menggunakan Aplikasi Expert Choice, Vol. 2, No. 5. Mei 20094.

[5] Meilia Nur Indah Susanti, 2011. Sistem Pendukung Keputusan Dengan Analytic Network Process ANP Untuk Penempatan Kerja Pada Sebuah Instansi, 2011.

[6] Pudji Astuti,et.al, 2011. Pemilihan Alternatif Pengelolaan Sampah Dengan Metode ANP dan Bocr .Universitas Trisakti Jakarta, Vol.VI. No 2. 2011.

[7] Luhur Priyantoko Aji, et.al 2010 Implementasi Performance Prism Untuk Sistem Pengukuran Kinerja Perusahaan (Studi Kasus: PT. Preshion Engineering Plastec Surabaya) 